\title{
Opening the bunker: function, materiality, temporality
}

\author{
Bradley Garrett (University of Sydney) \\ Ian Klinke (University of Oxford)
}

\begin{abstract}
Recent scholarship has drawn attention to a ubiquitous $20^{\text {th }}$-century political space that was long overlooked - the bunker. This body of work draws on a variety of theoretical influences and explores multiple historical contexts, yet most remains wedded to the late Paul Virilio's influential 1970s study of the Nazi Atlantic Wall. Enlightening as his 'Bunker Archeology' is, Virilio's theorisation has constrained contemporary debates around the function, materiality and temporality of the bunker. Here, we seek to counter this set of limitations in three ways. Firstly, we contest the idea of the bunker as a simple space of human protection and argue for a more expansive conceptualization that is attentive to the bunker as a site of extermination. Secondly, we challenge the assumed concrete materiality of the bunker and suggest an expanded typology, utilising a range of materials and milieux. Finally, we take to task readings of the bunker as an obsolete relic by highlighting the continued construction, reappropriation and reimagination of this architectural form.
\end{abstract}

\section{Keywords}

Bunkers, Subterranean, Preppers, War, Vertical 


\section{Introduction}

Underneath the English countryside in Wiltshire there is a 240-acre subterranean city that has, at various points in history, been called 'Stockwell', 'Subterfuge' and 'Turnstile'. Most locals know it as the 'Burlington Bunker' (Figure 1). Constructed in the late 1950s, the underground facility contains an industrial kitchen, sleeping quarters, a bomb-proof radio broadcasting station, and a library of documents needed to rebuild the government in the event of nuclear calamity. Walking through the complex, one can imagine a buzzing subterranean society enduring here in the first months of a post-apocalyptic period. While the space could seal off and shelter 4,000 people for weeks, it was not a space of potential protection from future threats as much as it was a possible command center, from which to rationalize and plan nuclear war. According to Royal Air Force (RAF) employee James Fox, 'its sole purpose in the 1950s was to detect an enemy attack from the former Soviet Union and relay that information to command so they could set off a retaliatory response' (Adams and McFadyen, 2016). These troglodytic propagators of remote extermination would come to know the smell of musty stone as home, for the walls are raw earth, a former Bath stone quarry. And yet the site was never inhabited; it was decommissioned in 2004, listed for sale in 2016 for $£ 1.5$ million and is currently being assessed for purchase by a private bunker developer who may reimagine the site within very different social and cultural frame, kitting it out to mitigate speculative threats posed by political, environmental and social collapse.

Like many other bunkers, Burlington defies our expectations of what constitutes a bunker in terms of its function (as a space of potential extermination), its materiality (with concrete playing little role), and by its surprisingly relevant temporality (enmeshed as it is in contemporary postsovereign geopolitics).

Figure 1. Inside Burlington Bunker (photo by author one, 2010).

Recent years have witnessed a wave of work from geography, anthropology and architecture that has grappled with the three-dimensionality of geopolitics (eg Weizman, 2007; Elden, 2013; Graham, 2016). In this turn to the vertical and volumetric, the focus has increasingly been on the way in which human bodies and the built environment interact in anticipation of particular kind of threats. Long discarded as uninteresting, one socio-cultural space that has received increasing attention within this debate is the bunker. Despite its crucial role as a monument to 'total war' (Virilio, 1975: 11), the bunker was long considered academic taboo, 'inglorious memorials of an age of secrecy and paranoia’ (Hirst, 2005: 221). As long as bunkers remained destinations where middle-aged male military enthusiasts took their sons and their political conservatism for a day out, it was difficult to conceive of them as sites for serious scholarship. Over recent years, however, the bunker has become a center of attraction amongst artists, journalists and academics alike and is now the subject of growing interdisciplinary attention.

Perhaps most obviously, the subterranean survival shell has been investigated as a site in which geopolitics, Cold War or otherwise, quite literally came to matter (Duffield, 2011; Vanderbilt, 2002; Montayne, 2012). Whilst some have read the bunker as a site of psychological and affective preparedness for war and annihilation (Masco, 2009), others have explored it as an ambivalent space and a waste of modernity (Beck, 2011). Others again have unpacked it as a space of 
exceptionality and biopolitics (Klinke 2018), probed the bunker's physical properties (Bartolini, 2015) and teased out the logics of re-appropriation, domestication and de-territorialisation that some bunkers invite, for bunkers compose, de- and recompose preparedness (Berger-Ziuaddin, 2017; Deville, Guggenheim Hrdličková, 2014). Finally, a growing strand of work has examined the bunker via notions of ruination and meaning-making through exploration (Bennett 2011a; 2011b; 2017a, Garrett 2013) and offered artistic engagement with this space (Sandys, 2017; Wilson, 2017).

In this then, the bunker joins a growing list of political spaces that have attracted scholarly attention, from the border (Sparke, 2006) to the camp (Minca, 2015), and from the airport (Adey, 2008) to the hotel (Fregonese \& Ramadan 2015). What makes the bunker stand out from these other crucial spaces is the sense that it has protected and encapsulated the very heart of the sovereign state in an age of total war. From the protection of the body politic during World War I (WWI) and World War II (WWII) in public shelters in Europe to the nuclear bunker in which the state's crucial organs could retreat in order to survive a war which would leave its territory destroyed and its population decimated, if not annihilated, the bunker protects so that its occupants can act. Yet today in much of the world, the abandonment of state provision of bunker space has led to a domination by private interests in the geopolitical trajectory of bunker construction, bringing it closer in some ways to these complementary political spaces. In other words, the bunker, once a space of exception, is being normalized, as both state and private actors move to 'secure the volume' (Elden 2013).

Theoretically, the growing literature on the bunker is a microcosm of larger debates in the social sciences and humanities, with papers drawing on a range of theorists including Giorgio Agamben, Gilles Deleuze and Jane Bennett, amongst others. And yet, whilst there is considerable theoretical variety framing the debate, the majority of contributions still remain indebted to the late Paul Virilio (1932-2018) and his seminal Bunker Archaeology, first published in French in 1975 and translated into English in 1994. In this study, the social theorist, architect and artist sets out to understand transformations in mid- $20^{\text {th }}$ century warfare through the prism of the Third Reich's Atlantic Wall fortifications. In doing so, Virilio grapples with the political essence and aesthetics of the $20^{\text {th }}$-century concrete survival shells he finds abandoned along the French coast.

In this article, we seek to lay bare Virilio's influential framing, and extend beyond it, in three ways. Firstly, we problematize the idea of the bunker as simply a space of survival. Whilst survival may be the 'product' that most bunkers promise, it is not the only thing they provide. In the $20^{\text {th }}$ century, bunkers frequently functioned as spaces from which survival's antithesis - extermination - was made possible, particularly through the planning of nuclear strikes or retaliation.

Secondly, we open discussion on Virilio's emphasis on the politics of poured concrete. The mere suggestion of the bunker is now almost synonymous with poured and reinforced concrete, and yet bunkers are far from reliant on the material of concrete; the most extensive bunkers in the world, like the Burlington Bunker in the opening paragraph, are more beholden to geology than casting. Additionally, many bunkers have been, and are, sheathed by steel rather than stone. Many contemporary bunkers have polyethylene integrated into their structure. The materiality of the bunker then is intertwined with its temporality: bunkers dug by hand in haste, systematically poured during wartime or methodically steel-lined over many years, betray distinctive geopolitical stories. 
Finally, we contend that the bunker has in fact not vanished, or even diminished, as an architectural form since the Cold War. Rather, subterranean imaginations have failed to keep pace with change and, as a result, have overlooked bunkers as a re-emerging form that is connected to but distinct from bunkers of the past. The contemporary private bunker construction economy and the activities of doomsday preppers, in particular, cast new light on the bunker as an evolving spatial archetype.

\section{Excavating the bunker}

Bunkers come in many forms and shapes. Whereas battlefield bunkers have had to be open so that projectiles can make their way from the bunker's inside to the outside, civilian air raid shelters and private luxury bunkers are meant to be self-sustaining closed-system environments where the necessary ingredients of human survival - oxygen, water and food - are secured over an extended timeframe. Despite this diversity of form and function, bunkers, we argue, are bound together by two primary attributes, which serves as an extended definition of the architectural form.

The bunker is, firstly, a human-built space and thus always socially and politically constituted. A cave, for instance, is not a bunker, unless it is transformed into one (Pérez, 2017). The anthropogenic - and indeed anthropocentric - underpinnings of bunkers are made clear in that they are constructed to protect economic/political elites and civilian populations (along with paraphernalia of survival) as needed in order to maintain the ideological superstructure of social and political life. Here, medieval fortified churches and subterranean crypts as Christian refuges (including, in the fourth century, the underground cities of Cappadocia) come to mind. Clearly, the bunker has its origins beyond the rise of the modern state.

And yet, while the bunker certainly has antecedents, it really takes shape only in the trenches of WWI, at a time when ideas about the struggle for space were morphing from their imperial origins into an explosive political mix that would soon give rise to fascist Lebensraum fantasies during WWII (Klinke, 2018). Particularly in Germany, geopolitics was articulated in relation to the soil, on whose resources the state was seen to be dependent. The aim of German geopoliticians was the creation of autarkic nation-states which could, as Rudolf Kjellén put it, survive behind closed doors, economically and politically (Kjellén 1917: 162). Whilst the infamous geopolitician and Nazi sympathiser Karl Haushofer had dismissed bunkers as a passive form of defence in the 1930s (he was thinking of the French Maginot line in particular), he changed his tune in the early 1940s when aerial bombardment had brought the question of subterranean survival to the forefront of military strategy (Haushofer, 1941). The autarkic underground living space of the bunker, from that point, functioned as a geopolitical expansion to the territorial fantasy of living space. The bunker thus materialised the idea of the state-as-organism that was rooted in its soil, steadfast against future threats. Thus, the bunker's form - indeed, its very existence - is a by-product of this socio-political milieu.

This brings us to our second definitional prong: bunkers are built to counter-balance speculative events and thus assume forms that reflect what is being anticipated. Even in cases where shelters were dug in wartime - we might think here of Malta's response to Mussolini's bombing campaigns - it was the speculation that bombing would continue that prompted excavation. When expectation 
of future catastrophe ceased, so did the construction and/or inhabitation of the space. The bunker thus has precursors in the history of military fortification as a space that can be inhabited, but where primary function is not habitation. Perhaps the most significant changes in form, however, were triggered by the invention, and use, of atomic and thermonuclear weapons, which forced bunker-builders deeper underground (where steel and stone played a greater role than concrete). Indeed, the exponential increase of nuclear explosive yields meant that the economic cost of excavation soon began to outweigh the political and psychological gains of hunkering down. This has led to both the abandonment of bunkers by governments (who no longer need to prop up Cold War state geopolitical ideologies) due to maintenance and upkeep costs, and the re-appropriation of those spaces by private actors who could never afford to have hollowed them out in the first place.

We contend that much of the literature around the bunker remains wedded to the idea that bunkers are a retrograde concrete architecture built to protect soldiers or populations on the battlefield. Further, we suggest this definition is limited precisely because it is being refracted through Virilio's reflections on the bunkers of WWII.

Paul Virilio is one of the more prolific and pessimistic thinkers to have emerged from post-war Europe. Born in 1932, he claimed to have been educated not in the lecture theatre but by peering onto the battlefield of WWII. It is thus perhaps no surprise that Virilio's work has drawn our attention to the often destructive, stealthy and yet (in his eyes) tremendously creative workings of the war economy. Unlike many Marxist theorists of his time, Virilio did not so much set out to explore the inner workings of contemporary capitalism as he attempted to understand the allpervasive nature of militarized authoritarianism. Fascism, for Virilio, was reborn in 1945 in the form of the Cold War state.

Virilio's books are deeply cynical thrillers about the ways in which modern society has lost its grip on the very technology that defines it as modern. They argue that a society in which fortifications are used to slow down the attacker has now given way to one built on the principles of speed and logistics, a society in which the distinctions between war and politics as well as between war and peace have evaporated (Virilio, 1977; Virilio and Lothringer, 1983). As speed has increasingly become the organizing principle of modern society, institutions that once governed interstate politics, such as territoriality and geopolitics (in fact space itself), are in Virilio's universe melting into thin air; think of nuclear missiles as spatially unbound agents that can annihilate cities anywhere on the planet without geographical constraints. For Virilio, the time-space compression of Harvey (1990) achieves apex through militarization.

Despite the thematic richness of Virilio's oeuvre, which covered issues such as globalization, technology, cinema, communication and the emergence of world cities, his Bunker Archeology remains amongst the most pathbreaking of his ideas and, in distinction from some of his later works, is generally seen to have aged well (Luke and Ó Tuathail, 2000: 361). Unlike many of his contemporaries, Virilio did not see the Third Reich's Atlantic Wall fortifications as aesthetic scars but rather as crucial precursors to the functionality of post-war concrete modernist architecture (Figure 2, also see Mould, 2015). Virilio was struck by the bunker's oblique angles, concrete monumentality and fluidity (concrete, after all, is poured). He read the bunker as a monolith whose elegant functionality would eventually herald the demise of national architectural styles. Having emerged in an era in which civilians had become legitimate targets of warfare, the monolithic bunker functioned for Virilio as a monument to total or 'absolute' war (Virilio, 1975: 40). 
Figure 2. Abandoned section of Atlantic wall bunker near Stavanger, Norway (photo by author two).

In Bunker Archeology, Virilio made several provocative arguments that continue to reverberate through, and to a degree bound, contemporary debates on the bunker. For instance, he read the bunker as a 'defensive architecture' (Virilio, 1975: 43); 'an architectural membrane against a hostile world' (Bratton, 2006: 19). Virilio's 'survival machine' was meant to resist 'shelling and bombing, asphyxiating gases and flamethrowers' (Virilio, 1975: 39). It was a last citadel 'where a long organization of territorial infrastructures comes to an end' (46). Furthermore, Virilio was enthralled by the bunker's concrete materiality. 'In concrete casting', he explained, 'there are no more intervals, joints - everything is compact; the uninterrupted pouring avoids to the utmost the repairs that would weaken the general cohesion at work' (45). Indeed, he wrote that the bunker's weight and materiality mean that it needed no fundament. Unlike other architecture, he held, the bunker did 'not aim to survive down through the centuries; the thickness of its walls translate[d] only the probable power of impact in the instant of assault' (39) for the duration of a future situation. Finally, Virilio read the bunker as an obsolete architectural form and emphasized that they had now transformed into 'historical ruins' - or perhaps accidental archaeology, taking the above into account (14). We get a sense of this in the following passage in which he recounts the moment in which he first became fascinated by the bunker:

scanning the horizon... with nothing interrupting my gaze, brought me full round to my own vantage point, to the heat and to this massive lean-to buttressing my body: this solid inclined mass of concrete, this worthless object, which up to then had managed to martial my interest only as a vestige of the Second World War, only as an illustration for a story, the story of total war (Virilio, 1975: pp 10-11).

Somewhat paradoxically then, Virilio understood the bunker both as a symbol of an era to come and as 'worthless', a form of architectural charlatanism, a psychological trick that sought to create in the gaze of the enemy the idea of impenetrability where there was really weakness and fear (Virilio, 1975: 47). The Atlantic Wall, after all, ultimately proved a strategic stillbirth, unable to stop the Allied landing in 1944, just as the vast bunkered Maginot Line had failed the French.

Whilst Virilio's work has attracted significant critique over recent years (Gane, 1999; author reference; Thrift, 2005) and has long been presented even by admirers with disclaimers as to its hyperbolic and paranoid undertones (Luke and Ó Tuathail, 2000: 364), his book on bunkers has remained largely unscathed (see for instance treatment of Virilio in Armitage, 2015; Beck, 2011; Bennett, 2017c; Elden, 2013; Klinke 2018). Enjoyable as the essays in his Bunker Archeology are to read, we would like to suggest, there are three areas that require renewed scholarly attention: function, materiality and temporality.

\section{Sheltering the Means of Extermination}

As we have already noted, the bunker has often been pitched by Virilio and his followers as a space of protection or in Virilio's words a 'survival machine' (Virilio 1975: 39). Drawing on Le Corbusier's formulation of the house as a 'machine for living in' (Le Corbusier 1986 [1931]: 95, 
240), Virilio's bunker operates 'like a factory; survival is its product' (Vanderbilt 2002: 139). The bunker's aims are thus passive aggressive - it seeks 'to hold and secure territory' through the survival of its occupants (Beck, 2011: 83). Already during World War II, bunkers had been viewed as a sort of infrastructure, a necessary public provision provided to those who could make it to one, or, in cases where shelter was limited, a space offered those who 'deserved' (and in some cases purchased) it. With such spectacular casualties mounting on the front, saving lives was crucial to geopolitical strategy. During the Cold War, the logic played out along a similar trajectory, though the scale changed as bunkers increasingly became a domestic architectural form of private responsibility (see see Szasz 2007). In the West, the Cold War state encouraged the construction of bunkers as an extension to the suburban or rural house (Berger Ziauddin, 2016; Masco, 2009). In Switzerland, this practice was legally codified and as of 2016 there was bunker space for 8.6 million individuals in a country of less than 8.4 million (Mariani, 2009).

Whilst bunkers certainly play a role in protecting what is within them from a hostile external environment, this is clearly not their only function. What Virilio fails to acknowledge is how large bunkered launch sites for the flying bomb (V-1) and the first ballistic missile (V-2) were in fact integrated into the Atlantic Wall in the early 1940s, suggesting that the 'littoral boundary' (Virilio, 1975: 10) was in fact offensive from its inception. Located in Northern France, these sites were meant to blast volleys of these 'redistribution weapons' at London and the South-East of England. Supported by Hitler and criticized by large parts of the Wehrmacht leadership as constituting obvious targets for enemy air raids, the sites were incapacitated by the Allied campaign 'Operation Crossbow' before they could unleash their destructive force (Kaufmann and Kaufmann, 2003: 296). Though ultimately ineffective, sites like the gigantic domed 'La Coupole' near Calais, France (Figure 3) foreshadowed the changing nature of the bunker as subterranea increasingly became a space of active and imagined extermination. Since industrial centers had become the target of aerial bombing campaigns of the early 1940s, the production of crucial armaments was moved into bunkered sites. It is in this light that David Monteyne (2011: xix) rightly notes that the bunker is 'both defensive and offensive', even if he does not explore the implications of this statement.

\section{Figure 3. Cross-section of La Coupole bunkered missile launch site near Calais, France (image via wikicommons).}

Although sites like La Coupole were thus never able to produce the urbicide they were meant to unleash, they were in fact prototypes of the intercontinental ballistic missile (ICBM) launch sites that would define the Cold War era. Indeed, many US and Soviet ICBMs were to be launched from subterranean sites, which were themselves bunkered living spaces. In the United States, these launch facilities had colorful names such as Atlas, Titan, Peacemaker or Minuteman; they were 'terrestrial submarines', each of which was a 'colony-like assemblage of tunnels and subterranean domes’ (Vanderbilt, 2002: 161). As Heefner (2012: 111) has written about the Minuteman silos, at any given moment during the Cold War, no fewer than 200 Air Force officers lived 80 feet underground waiting and hoping that 'the job they had been trained to do would never have to be done'.

Zygmunt Bauman has argued that 'survival is targeted on others, not the self' and that we 'live through the death of others, and their death gives meaning to our success: we are still alive' 
(Bauman, 1992:10, emphasis in original). Thus, much like the concentration camp, the bunker should be read as a biopolitical space, as conceptualized by Giorgio Agamben (1998). Not only have states used bunkers to govern populations by promising to protect (worthy) lives, but they have also used them as spaces from which to plan and unleash total war. It was of course from his own command bunker that Hitler, in the final stages of the war, ordered the destruction of the Third Reich's vital infrastructure in order to annihilate the German people, who he deemed to have proven inferior in the struggle for Lebensraum (Fest, 2005).

Thus, as Roberto Esposito (2008: 10) has noted, the Führerbunker was not just a shelter, but a thanatopolitical space, the last retreat of a state that had turned its protective apparatus against itself, like an autoimmune disease. During the Cold War, command bunkers in which political and military elites would have survived a limited nuclear exchange made such a genocidal war more likely than if these elites had remained unprotected. The bunker allowed for the playing out of the ultimate offensive thought experiment. Bunkers were spaces of exception, where democratic states could morph into autocracies in times of war by making the decision to sacrifice the polis from this space of protection. The distinction between the function of these bunkers with the public shelters of WWII is thus rendered clear, the form reflecting growing social inequality and changing speculative imaginations of disaster.

As Masco (2009) suggests, large-scale state bunkers always played dual roles. The United States NORAD (North American Aerospace Defense Command) facility for instance - buried 2,400 feet inside the Cheyenne Mountain Complex in Colorado - was 'simultaneously the most isolated and the most connected site in the United States' (Masco, 2009: 17), an infrastructure meant to preserve not just human lives but also the ability to detect missiles, satellites, and foreign aircraft both before and after a strike, and to respond to threats via an embedded subterranean Ballistic Missile Defense Center. Interestingly, a number of Atlas Missile launch facilities have now been converted into heavily secured private retreats for the wealthy, making them not only previous spaces of extermination but also far from obsolete. We will return to this point below.

\section{Multiple Materialities}

Part of the preoccupation with the bunker as a static concrete shell is rooted in the extensive use of reinforced concrete by the Third Reich in the construction of both its air raid shelters and the iconic Atlantic Wall. Yet the Nazis had a difficult relationship with concrete. The concrete of early above-ground urban bunkers (Hochbunker) was often clad with stone and fitted with emulated medieval ornamentation, because concrete was not seen to blend with the neo-medieval city the Nazis imagined (see Figure 4). The Nazi architect Albert Speer claimed in his memoirs that he had designed his buildings according to a 'Theory of Ruin Value' (Ruinenwert), which applied materials and 'certain principles of statics' so as to produce beautiful ruins in centuries or millennia to come (Speer, 1970: 56, also see Featherstone, 2005). Here we see a connection between survival in the bunker and the imagination of future ruins; with 'immortality not being a viable option, survival means living longer than others' (Bauman, 1992: 26, emphasis in original). Survival here is a phenomenological and architectural proposition.

Figure 4. Converted Reichsbahnbunker in Berlin (built in 1943), exhibiting signs of WWII urban warfare (photos by author two, 2014). 
In Bunker Archaeology, Virilio focuses on the properties of the monolithic casemate, and especially on the transition from liquid to solid concrete. Virilio's conception of the bunker as a monolithic form has not been without its critics (Hirst, 2005: 213) and yet, a focus on poured and reinforced concrete has remained at the heart of bunker imaginaries to the degree that 'bunker and concrete are almost synonymous' (Bennett, 2017b: 10; see also discussion in Forty, 2012: 169172). Bartolini (2015) has made an argument for a reading of the bunker's materiality through vitalist theory. She highlights the liquid malleability of concrete as a key to an understanding of the bunker, despite cautioning against any simplistic material causality. We would add that even where concrete is poured over breeze-blocks or between formwork, the materials that enable the transformation from liquid to solid are as intrinsic to the materiality of the bunker as the concrete remainder.

Further, although Beck (2011: 81) refers to bunkers as 'concrete blankness', not all bunkers use poured and reinforced concrete, the most obvious departure being where the geology itself is conducive to the production of bunkered space. Virilio goes so far to suggest 'that the mineral element became a part of the fluidity and flow, of concrete', dismissing offhandedly 'the exception of rock' (Virilio, 1975: p. 38), despite the most ubiquitous and oldest form of the bunker being the excavated bunker. To return to Malta, for instance, it is a country riven with bunkers that were excavated from limestone with pickaxes - no concrete is to be found in their construction. The solubility of limestone itself invites tunneling, transforming the material into 'geologicalgeopolitical spaces’ (Squire, 2016: 551). Russia's Yamantau Mountain in the Ural Mountains, to provide another example, was hollowed out to shelter 60,000 people under thousands of feet of quartz (Phelan, 2004). Virilio claims that the 'monolith' of the bunker has no foundation, but of course its foundation is geological. Whether a bunker is poured or carved, and regardless of whether it is surficial, semi-subterranean or buried, the materiality of the bunker is anthrogeologic. Rock shields the bunker, both from attack and from view, and part of its capacity for protection and extermination is formed in the harbor that rock provides.

During WWII, many bunkers were not so much built as adapted from other subterranean infrastructure. During the Blitz, parts of the London Underground were re-appropriated as air raid shelters. These tunnels, built using a 'cut-and-cover method', were trenched from the surface, lined by bolted cast-iron cross girders, sheathed in brick and then reburied (see Clayton, 2010: 161), and made for excellent bunkers. West German public bunkers were increasingly designed into new UBahn stations, car tunnels and underground car parks during the Cold War. In Pyongyang, North Korea, as well as in a large part of the former Soviet Union, the Metro was designed from inception to double as a nuclear bunker (Figure 5). This is not to suggest that these sites were built without the use of reinforced concrete, but rather that it is misleading to single out concrete as the bunker's defining material.

Bunkers have been formed from other materials, including steel, polyethylene and even buried school buses (Blank 2018). In recent years, shipping containers have become one of the most ubiquitous forms of domestic shelters, since they can be readily (and inexpensively) obtained from port facilities and can be buried with a small backhoe in 20-foot deep holes surrounded by gabion baskets. In the UK, before and during World War II, 3.5 million Anderson shelters - constructed from fourteen sheets of corrugated iron - were built, making it by far the most ubiquitous form of shelter in the history of the country (Field, 2014: 6). 
Figure 5: Arsenalna metro station in Kiev, Ukraine, is the deepest metro station in the world (at $105.5 \mathrm{~m}$ or 346ft) and doubles as a nuclear bunker when blast shields are lowered (photo by author one, 2018).

What the reduction of the bunker to a monolithic concrete crypt thus veils is that bunkered space is not always static and frozen but can be tremendously dynamic and mobile. Indeed, there is a larger geography of human fortification to be written here. If the revival (or continuation) of the bunker in the early $21^{\text {st }}$-century is to be comprehended, then the political effects of a broad range of materials that are recruited into the hardening of human existence need to be critically engaged. Virilio argues that the concrete bunker is anthropomorphic (Virilio, 1975: p. 13), leading later scholars to argue that bunkers anthropogenically transform the landscape through archaeological scarring (Glass, 2017). Yet these concrete casemates, visible on the surface of the earth, Virilio's monoliths, have been anthropogenically overshadowed by the subterranean, out-of-sight, geological coring taking place in the construction of modern bunker facilities, both public and private. It is largely to the latter that we now turn.

\section{A Subterranean Renaissance}

Bunkers have, until recently, been 'too modern' to be archaeological. Abandoned Royal Observation Corps posts in the UK, domestic atomic shelters across the United States and aboveground air raid shelters in German cities were roundly ignored by the heritage industry. Increasingly however, along with wider scholarship on bunkers, they are seen as harboring potential cultural value and bunker museums are now proliferating in many cities on both sides of the former iron curtain. Whilst such museums may not (yet) attract the footfall that castles or sites of dark tourism do, there is now a sense in the heritage industry that bunkers are 'retro, quirky and cool' (Bowers and Booth, 2017: 213). And yet, bunkers are still often treated by these museums as an obsolete architectural form left behind from a time when threats and loci of power were different. As it has become increasingly popular to suggest that we live in the most peaceful age in human history (Pinker, 2012), the bunker is rendered an outmoded architectural form that establishes a contradistinctive connection to a past that has forever disappeared into the dark folds of the $20^{\text {th }}$-century.

Interestingly, there were always voices that argued the bunker was doomed to obsolescence. As Vanderbilt (2002: 131-2) has shown, the architect of the British bombing campaign of German cities Arthur 'Bomber' Harris did not think much of bunkers (along, of course, with Haushofer). Indeed, the creation of fire-storms by Allied air raids often turned the aforementioned Hochbunker into furnaces that roasted their inhabitants alive. Tendencies to denote the bunker as a useless and obsolete architecture continue into the present, with John Beck echoing Virilio in suggesting that 'the bunker is the waste of modernity' (Beck, 2011: 83).

However, the above does not account for the robust contemporary bunker construction economy. This is not simply a case of bunkers having an afterlife where they are adopted and appropriated as nightclubs, underground farms or secure file storage facilities - in recent years there has actually been a surge in the construction of new bunker spaces by both state actors and private citizens. 
Clearly many people, in both civilian and government contexts, continue to think of the bunker as useful - and potentially necessary.

In regard to the former, although civil defense programs were dropped after the fall of the Berlin Wall and many subterranean refuges were simply abandoned, bunkers have not disappeared from the security state's radar. According to U.S. Defense Department estimates, there were approximately 10,000 underground military installations in the world just over a decade ago, many of which were not visible from the earth's surface (Phelan, 2004). In Russia, large-scale public and military bunkers are still being built (Nilson, 2018). In North Korea, a subterranean weapons factory is believed to employ as many as 20,000 workers (Phelan, 2004). In its efforts to foil dictators, smugglers and terrorists, the US military is developing deep ground-penetrating radar and gravity-measurement technology that could render such bunkers visible (Chambliss 2018, Bell, 2008; Graham, 2016: 342).

However, it is private individuals and companies who are fueling the construction of much bunkered space today. A populace growing increasingly anxious due to media narratives about sociopolitical instability are increasingly seeking necessary subterranean 'upgrades' to the home like armories, long term food storage facilities, and panic rooms. Between 2001 and 2014, planning applications for 'mega-basement' developments in London's Borough of Kensington and Chelsea rose from 46 to 450 (Graham, 2016: 314). Many of these projects contain panic rooms and other 'hardened' elements. Since the subterranean volume of these excavations can exceed the size of the street-level house several times, Wainwright (2012) has suggested calling this 'iceberg architecture'. Mark Duffield (2011: 3) has gone so far as to suggest that the bunker, like many of the technologies we use, has achieved escape velocity from its military origin and become 'the signature architectural form' of late-stage capitalism, embodied as it is in malls, airports, and gated communities. Neoliberalism meets geopolitics in these new bunkers.

As Naomi Klein (2017: 351) writes, 'in Silicon Valley and on Wall Street, the more serious highend survivalists are hedging against climate disruption and social collapse by buying space in custom-built underground bunkers'. Rising S, a company just outside of Dallas, Texas, recently delivered two 1,000-square-foot steel bunkers to New Zealand for a client building a location to 'bug out to' in the event of a global pandemic, stock market crash, or populist uprising. The owner of the company, Gary Lynch, told Bloomberg that 'Seven Silicon Valley entrepreneurs have purchased bunkers from Rising S Co. and planted them in New Zealand in the past two years' (Carville 2018, np). If unease about speculative calamity triggers a 'flight' instinct in some people, in others it catalyzes a desire to hunker down.

Trident Lakes in Texas and the Survival Condo in Kansas, for example, are part of a growing desire to 'prep' for various apocalyptic scenarios without necessarily forgoing the comforts of late liberal capitalism (for more ‘consumable immortality' see Foster 2016). Trident Lakes is a proposed 1-square mile complex of 850 semi-subterranean bunker spaces, formed from concrete, steel rebar, and epoxy resin being sold for up to \$2 million dollars each, touting itself as an ultrasecure bunker playground for the wealthy. The property will include, according to former spokesperson Richie Whitt, 'three blue lagoons, 5-star spa, gun ranges, golf course, equestrian center, helipads, learning campus and 15-foot security wall'. The project, however, is currently on hold pending federal investigation of the founder for money laundering.

Survival Condo, meanwhile, is a complete, and sold out, repurposed Atlas ' $F$ ' missile silo in the middle of a corn field. In contains 75,000 gallons of water, nuclear, biological, and chemical 
(NBC) air filtration, food production facilities, general store, and a command and control centre. It is secured by 9-foot-thick walls, 24-hour armed guards and motion-sensing gun turrets. 3,600square-foot penthouses in the facility sold for \$4.5 million USD, reminiscent of the luxury Cold War shelters built by Jay Swayze (see Szasz 2007: 45). A second silo is currently under construction which the owner assured us would 'be a bit more expensive'.

For preppers with a more modest budget in mind, and South Dakota's $x$ Point is a community of people currently moving into 575 derelict munitions bunkers which are to be converted into what the founder, Robert Vicino, has described as 'the largest prepper community in the world' (see Figure 6 and Figure 7). Interviews with residents revealed a laundry list of concerned prompting their move into the facility, which was reflected in the way the bunkers were being designed against nuclear, biological, and chemical attack, physical assault, flooding and electromagnetic threats, for instance. In the Vivos Group's xPoint development, middle income families can enter into a 99-year lease on a ready-to-retrofit Army Corps of Engineers bunker for \$25,000. As the complex expands it is meant to assuage unmoored fear through the creation of intentional community. This is also not the only Vivos property. In addition to a sold-out bunker in Indiana, Vicino is currently negotiating the potential purchase of the Burlington Bunker in the UK from the opening vignette.

Figure 6. An empty xPoint bunker in South Dakota (image by author one, 2017).

Figure 7. A completed xPoint 'show bunker' (image by author one, 2018).

Clearly, prepping today, though still taking place in bunkers - and interestingly here taking shape in World War II and Cold War munitions bunkers - is arranged on a broader scale and is no longer necessarily about protecting general citizenry or the 'nuclear family', but about building a community that will hold fast before, during and after an apocalyptic event, no longer limited to a specific disaster imagination. These prepping activities, though similar to the back-to-thewilderness survivalism of the past (see Mitchell 2002), reflect a changing social and political situation that indicates the bunker may not be as historically confined as is often assumed. It is thus important to expand the assumed temporality of the bunker. Beck (2011: 82) notes that 'the bunker promises security and control in the form of refuge... both womb- and tomb-like'. This narrative of the bunker as a womb from which to be reborn plays out in popular media, where protagonists often emerge after a catastrophic event to find that global governance at the level of the nation-state has collapsed, victims of its own nuclear ambitions. Now 'free', society reforms along neo-tribal lines in a libertarian post-apocalyptic hunter-gather fantasy.

Rather than becoming redundant, the bunker is no longer where society is saved but where the individual is preserved (it is no coincidence that cryogenic body freezing operations also take place in bunkers). Instead of providing a refuge in which the citizen can bond with the state, the individual, and perhaps a hand-selected cohort, is shielded from the state. In popular North American prepper narratives today, the state has no role in the bunker society. As Shapiro and Bird-David (2016: 647) argue in regard to mamad bunkers in Israel, the exclusive privatisation of 
subterranean domestic security 'constitutes a sense of privileged enclosure' that reflect current geopolitical realities.

Just as the steel used by Rising S and epoxy used by Trident Lakes renders their materiality more multiple, and the very fact of their construction challenges assumptions about temporality, we can also return to consideration of function. All of the bunkers discussed above were engineered to mitigate particular future anxieties, whether these be spoilage, butchery, or bombing. Many contemporary bunkers, such as those being built by doomsday preppers, in contrast, are being constructed not in anticipation of specific events but to counter unspecific unease about social, political and/or environmental collapse.

Though contemporary bunkers may be built to counter a wider range of 'anxious expectations', as with bunkers of the past their form continues to reflect the speculative events that they will be called into operation for and calls for an expanded typology. Function and materiality, in other words, were always beholden to the temporality of speculative events, and increasingly eventful prediction is uncertain. The rise of the doomsday prepping industry in today's media-driven geopolitical climate comes as no surprise to those who have noted the affective economy of fear that characterizes contemporary life in places like the USA and UK.

\section{Conclusion}

In this article, we have proposed that the bunkered architectural form is worthy of continued attention due both to its persistence and morphism. Dominant understandings of the bunker, we have argued, remain too indebted to Paul Virilio's formulation of the bunker as a defensive architecture, a concrete casting and a ruin.

We have already noted that Virilio's theorization was written with a specific agenda in mind. Virilio was at the early stages of his career promoting the bunker's oblique lines as an architectural alternative to (medieval) horizontality and (modern) verticality. Virlio's thinking accreted around experiences in his 'bunker church' of Sainte-Bernadette du Banlay. But this imagination needs to be expanded to allow for the bunker's aggressive (rather than just passive aggressive) nature, its complex (rather than merely concrete) materiality and its continued relevance in a new age of survivalism to be fully appreciated. In our final paragraphs, we highlight two areas that require attention for the growing body of work investigating the subterranean geographic and the geopolitical geologic.

The first of these concerns the current narrative perimeter around bunkers and calls for a Janusfaced investigation into both the more multiple pasts and the anticipated futures of the bunker. As we have demonstrated, the bunker's complex, and ongoing, history has seen it morph from a military infrastructure to a public utility and then into a private architectural extension and, perhaps finally, a communal off-grid subterranean suburb. Clearly, the story of the bunker did not end with the desertion of the Cold War era family fallout shelter and we call for a rethinking of the bunker as an evolving architectural typology rather than a static form.

Secondly, and finally, the bunker is a space of bodies beyond the flesh, affording protection to infrastructural bodies: fiber optic cables, nodes, relays and data storage facilities (see Fish and Garrett 2018). The housing of these ex-bodies reforms the bunker, like the transport tunnels of WWII, as a meta-infrastructure. A spatial history is yet to be written of the subterranean protection 
afforded to the very infrastructure that sustains and secures modern life. More-than-human theorizations of the bunker might further be extended into the storage of nuclear waste in Yucca Mountain, Nevada, for instance (see Houston, 2013) or seeds in the Svalbard global seed vault in Norway (see Moss, 2016). Doing so would realign our conceptions of the form and function of the bunker, without reducing it to a 'a pure representation of function in poured concrete' (Vanderbilt, 2002: 36). Consideration of the more-than-human bunker will inevitably verge into new geographic territory, not simply in volumetric terms, where we began this paper, but into places both proximal and distal where geography is being reimaged. These (other) complex histories of the bunker are under-narrated and not convincingly embedded within the larger histories of fortification and biopolitics. We hope to see future research open the bunker even beyond the questions of function, materiality, and temporality that we have highlighted in this piece.

\section{Bibliography}

Adams M and McFadyen, S (2016) Cold war bunker for sale for £1.5m. Mirror Online, March 4, Available at http://www.mirror.co.uk/news/uk-news/cold-war-bunker-sale-15m-7495465 (accessed 17 October 2017).

Adey P (2008) Airports, mobility and the calculative architecture of affective control. Geoforum 39: 438-451.

Agamben G (1998) Homo Sacer: Sovereign Power and Bare Life. Stanford: Stanford University Press.

Armitage J (2009) Virilio: selected interviews. London: Sage.

Armitage J (2015) Virilio for architects. London and New York: Routledge.

Bartolini N (2015) The politics of vibrant matter: Consistency, containment and the concrete of Mussolini’s bunker. Journal of Material Culture 20: 191-210,

Bauman Z (1992) Survival as a Social Construct. Theory, Culture and Society 9: 1-36.

Beck J (2011) Concrete ambivalence: Inside the bunker complex. Cultural Politics 7: 79-102.

Bennett L (2011a) Bunkerology - a case study in the theory and practice of urban exploration. Environment and Planning D 29: 421-434.

Bennett L (2011b) The Bunker: Metaphor, materiality and management. Culture and Organization 17: 155-173.

Bennett L (2017a) The ruins of the Cold War bunker: Affect, materiality and meaning making. London: Rowman and Littlefield International)

Bennett L (2017b) Approaching the bunker: Exploring the Cold War through its ruins. In: L Bennett (ed) The ruins of the Cold War bunker: Affect, materiality and meaning making. London: Rowman and Littlefield International, pp.3-21.

Bennett L (2017c) Entering the bunker with Paul Virilio: The Atlantic Wall, pure war and trauma. In: L Bennett (ed) The ruins of the Cold War bunker: Affect, materiality and meaning making. London: Rowman and Littlefield International, pp.23-38.

Bell D F (2008) Bunker busting and bunker mentalities, or is it safe to be underground? South Atlantic Quarterly 107: 213-229. 
Blank, Lew (2018) Ark Two Shelter. Atlas Obscura https://www.atlasobscura.com/places/arktwo-shelter (accessed $7^{\text {th }}$ September 2018)

Bowers R and Booth K (2017) Preserving and managing York Cold War bunker. In: L Bennett (ed) The ruins of the Cold War bunker: Affect, materiality and meaning making. London: Rowman and Littlefield International, pp.201-214.

Berger Ziauddin S (2017) (De)territorializing the home: The nuclear bomb shelter as a malleable site of passage. Environment and Planning D 35: 674-693.

Bratton B (2016) Foreword. In P. Virilio P. 1977. Speed and Politics.. Los Angeles: Semiotexte): 7-25.

Chambliss, W (2018) Gravity. Environment and Planning D: Society and Space.

Carville, O (2018) The Super Rich of Silicon Valley Have a Doomsday Escape Plan. Bloomberg News. $5^{\text {th }}$ September.

Clayton A (2010) Subterranean City: Beneath the Streets of London. Whitstable: Historical Publications.

Deville, J. Guggenheim M. Hrdličková, Z. (2014) Concrete governmentality: Shelters and the transformations of preparedness. The Sociological Review 62: 183-201

Duffield M (2011) Total war as environmental terror: linking liberalism, resilience and the bunker. South Atlantic Quarterly 110: 757-769.

Elden S (2013) Secure the volume: Vertical geopolitics and the depth of power. Political Geography 34: 35-51.

Esposito R (2008) Bios: Biopolitics and Philosophy, Minneapolis: University of Minnesota Press.

Featherstone M (2005) Ruin Value. Journal for Cultural Research 93: 301-320.

Fest J (2005) Inside Hitler's bunker: The last days of the Third Reich. London: Pan Books. Foster GA (2016) Consuming the Apocalypse, Marketing Bunker Materiality, Quarterly Review of Film and Video. 33(4): 285-302.

Field J F (2014) D-Day in Numbers: The facts behind Operation Overlord. London: Michael O'Mara Books.

Fish, A and Garrett B L (2018) Resurrection from Bunkers and Data Centres. Culture Machine. Online First.

Forty A (2012) Concrete and culture: A material history. London: Reaktion.

Fregonese S and Ramadan A (2015). Hotel geopolitics: A research agenda. Geopolitics, 20: 793813.

Gane M (1999) Paul Virilio’s bunker theorizing. Theory, Culture and Society 16: 85-102.

Garrett, B L (2013) Explore Everything: Place-hacking the City. London: Verso.

Glass (2017) Once upon a time in Ksamil: Communist and post-communist biographies of mushroom-shaped bunkers in Albania. In: L Bennett (ed) The ruins of the Cold War bunker: 
Affect, materiality and meaning making. London: Rowman and Littlefield International, pp.201214.

Graham S (2016) Vertical: The city from satellites to bunkers. London: Verso.

Harvey D (1990) Harvey, David. The Condition of Postmodernity: An Enquiry into the Origins of Cultural Change. Cambridge, MA: Blackwell.

Haushofer K (1941) Wehrgeopolitik, $4^{\text {th }}$ and $5^{\text {th }}$ edition. Berlin: Junker und Dünhaupt.

Heefner G (2012) The missile next door: The Minuteman in the American Heartland, Cambridge and London: Harvard University Press.

Hirst P (2005) Space and power: Politics, war and architecture. London: Polity.

Houston D (2012) Environmental Justice Storytelling: Angels and Isotopes at Yucca Mountain, Nevada. Antipode 45: 417-435.

Kaufmann J E and Kaufmann H W (2003) Fortress Third Reich: German fortifications and defensive systems in World War II. Cambridge: Da Capo Press.

Kjellén R (1917) Der Staat als Lebensform. Leipzig: S. Hirzel.

Klein N (2017) No is Not Enough: Defeating the New Shock Politics. Allen Lane: London.

Klinke I (2018) Cryptic concrete: A subterranean journey into Cold War Germany (Oxford: Wiley-Blackwell)

Mariani D (2009) Bunkers for All. Swiss Broadcasting Corporation, July 3. Available at: https://www.swissinfo.ch/eng/prepared-for-anything_bunkers-for-all/995134 (accessed 17 October 2017).

Masco J (2009) Life Underground. Building the Bunker Society. Anthropology Now 1: 13-29.

Minca C (2015) Geographies of the Camp. Political Geography 49: 74-83.

Monteyne D (2011) Fallout shelter: Designing for civil defence in the Cold War, Minneapolis: University of Minnesota Press.

Moss A (2016) After the End: Svalbard Global Seed Vault. In Global Undergrounds: Exploring Cities Within. Edited by Paul Dobraszczyk, Carlos López Galviz and Bradley L. Garrett.

London: Reaktion Books: pp. 248-249.

Mitchell R (2002) Dancing at Armageddon: Survivalism and Chaos in Modern Times. Chicago: Chicago University Press.

Mould O (2015) Brutalism Redux: Relational Monumentality and the Urban Politics of Brutalist Architecture. Antipode 49: 701-720.

Le Corbusier (1986 [1931]) Towards a New Architecture. Mineola, N. Y: Dover Publications.

Luke T and Ó Tuathail G (2000) Thinking geopolitical space: The spatiality of war, speed and vision in the work of Paul Virilio. In: M Crang (ed) Thinking space. London: Routledge, pp.360379.

Pérez M A (2017) Bunker and cave counterpoint: Exploring underground Cold War landscapes in Greenbrier County, West Virginia. In: L Bennett (ed) The ruins of the Cold War bunker: 
Affect, materiality and meaning making. London: Rowman and Littlefield International, pp.113129.

Pinker S (2012) The Better Angels of Our Nature: Why Violence Has Declined. New York: Penguin.

Phelan B (2004) Buried Truth. Harper's Magazine, December Issue.

Robinson M (2017) These doomsday shelters for the 1\% make up the largest private bunker community on earth. Business Insider, January 2. Available at:

http://www.independent.co.uk/life-style/these-doomsday-shelters-for-the-1-make-up-the-largestprivate-bunker-community-on-earth-a7507926.html (accessed 17 October 2017).

Sandys K (2017) Sublime concrete: The fantasy bunker, explored. In: L Bennett (ed) The ruins of the Cold War bunker: Affect, materiality and meaning making. London: Rowman and Littlefield International, pp.57-73.

Shapiro M (2017) Routinergency: Domestic securitization in contemporary Israel. Environment and Planning D 35: 637-655

Sparke M (2006) A neoliberal nexus: economy, security and the biopolitics of citizenship on the border. Political Geography 25: 151-180.

Speer A (1970) Inside the Third Reich, London: Phoenix.

Squire R (2016) Rock, water, air and fire: Foregrounding the elements in the Gibraltar-Spain dispute. Environment and Planning D 34: 545-563.

Szasz, A (2007) Shopping Our Way to Safety: How We Changed from Protecting the Environment to Protecting Ourselves. Minneapolis: University of Minnesota Press.

Nilson, T (2018) Satellite images reveal Russian navy’s massive rearmament on Kola Peninsula. The Barents Observer. Available at https://thebarentsobserver.com/en/node/4370 (accessed 19 September 2018).

Thrift N (2005) Panicsville: Paul Virilio and the esthetic of disaster. Cultural politics 1: 353-364.

Vanderbilt T (2002) Survival city: adventures among the ruins of atomic America. New York: Princeton Architectural Press.

Virilio P (2000) Ctheory Interview with Paul Virilio. Paul Virilio in Conversation with John Armitage, Ctheory article a089.

Virilio P (1975) Bunker archaeology. NY: Princeton Architectural Press.

Virilio, P (1977) Speed and Politics. Los Angeles: Semiotexte.

Virilio P and Lotringer S (1983) Pure War. New York: Semiotexte.

Wainwright O (2012) Billionaires' basements: the luxury bunkers making holes in London streets, Guardian Cities, $10^{\text {th }}$ November. Available at:

https://www.theguardian.com/artanddesign/2012/nov/09/billionaires-basements-london-housesarchitecture (accessed 17 October 2017).

Wilson L (2017) Processual engagements: Sebaldian pilgrimages to Orford Ness. In: L Bennett (ed) The ruins of the Cold War bunker: Affect, materiality and meaning making. London:

Rowman and Littlefield International, pp.75-93. 